\title{
ECONOMIC AND NATURAL EFFECTS OF NITRATE POLLUTION OF AGRICULTURAL ORIGIN, IN PARTICULAR THE AQUATIC ENVIRONMENT \\ ${ }^{1}$ R. Matos, ${ }^{2} \mathrm{~J}$. Gál, ${ }^{3} \mathrm{~B}$. Zsótér, ${ }^{4} \mathrm{C}$. Timofte \\ ${ }^{1-3}$ University of Szeged, Faculty of Engineering, Mars tér 7,6724, Szeged, Hungary \\ ${ }^{4}$ University of Oradea, Faculty of Law, Generalul Magheru 26, 410087, Oradea, Romania \\ e-mail: galj@mk.u-szeged.hu
}

\begin{abstract}
The whole area of Hungary is the gathering ground of our principal rivers (Duna, Tisza) and some bigger lakes, like Balaton, Fertö lake and Velencei lake. The water isn't only staff of life; it is one of the most sensitive biotope of world. We suppose to protect our aquatic environment from environmental pollution as such nitrate pollution or eutrophication. Trough agricultural production the nutrient rate increases in water. The weeds begin to pullulate, they are taking up more oxygen from the water, they are necrosis, the depth of warp increases faster so the eutrophication drowns on, and the nitrate rate of rivers increases.
\end{abstract}

Keywords: environmental economics, water treatment, nitrate, Balaton lake, Fertő lake

\section{INTRODUCTION}

Our country colloquially known as the "Water country", not in vain, since many of the river travels across the whole territory of the country, our country, the Danube and the Tisza river drainage basin covers the area, and as of great importance, we can take pride as the lake Balaton, lake Velencei or lake Fertö, and we have high-volume underground water resources. However, it is highlighted the water discharge of only 5\% of our rivers-the is originated in Hungary, the rest of the water flow through the country, just as the Geographical Institute of the Hungarian Academy of Sciences (MTA FKI) published in paper titled Surface and groundwater [3]. Since most of our vulnerable water-based area, so increasing the protection of our waters.

Starting in the 1960s the industrial farming increased rapidly gaining ground. At the same time the development of agriculture has changed the soil's fertility, physical, chemical parameters. By modernization of agriculture soil fertility of the soil quality can be improved, but above a limit the opposite effect can be seen. Minor changes by easier interaction (e.g. liming) is compensated, or nature can balance it without any intervention, while more serious lesions may cause an irreversible process. [6] Nemeth and co-authors mention in 2007, among others, in the same time, such as nutrient balance displacement, prolonged toxicity of fertilizers in the soil is carried out, in addition to the accumulation of nutrients (e.g. nitrate), which might have adverse effects on your health.

During industrial agriculture time was characterized the production of high yields, by entering a lot of external energy (fertilizer, pesticides, mechanical work) could be achieved [7]. high degree of mechanization was necessary to cultivate large areas, which further increased the environmental impact. As a result of the powerful automation on the soil properties of deteriorated. For example, the content of organic matter and reduction of biological life, acidification, salinization, water table further to restore the power that the subsidence, and the use of chemical substances. High percentage of mechanization and negative consequences of chemical usage was not initially, but later on, in spite of the increasing input use was becoming more difficult to maintain a high average yield, increasingly manifested the dark side of the industrial farming. [1]

The '70s years of fertilizer consumption nearly tripled in Western Europe, which further increased the environmental impact. In vain began the mapping of agricultural regions, on the basis of the average of the samples taken from the fields of the nutrient supply, whereas the then technology did not allow for different levels of application. Not only the industrial agriculture made environmental degradation, but caused big extra cost to obtain the extra inputs. [2] 
Domestic researchers [6, 7] were examined for the period 1970-1990, Hungary is characterized by chemical and it was found that our country's use of fertilizer along the Western European level was also accounts for up to half the chemicals we were able to achieve outstanding yields. According to Kádár [7] in our country so close to $1 / 3$ more exposure than the nutrient has been added. Kádár's (2005) statement was confirmed by Németh (2007). Figure 1 shows the fertilizer spreader. In '70 - '90s were not able to meet the needs of the plant and the soil nutrient content of the fertilizer, therefore implies the positive balance of the soil nutrients.

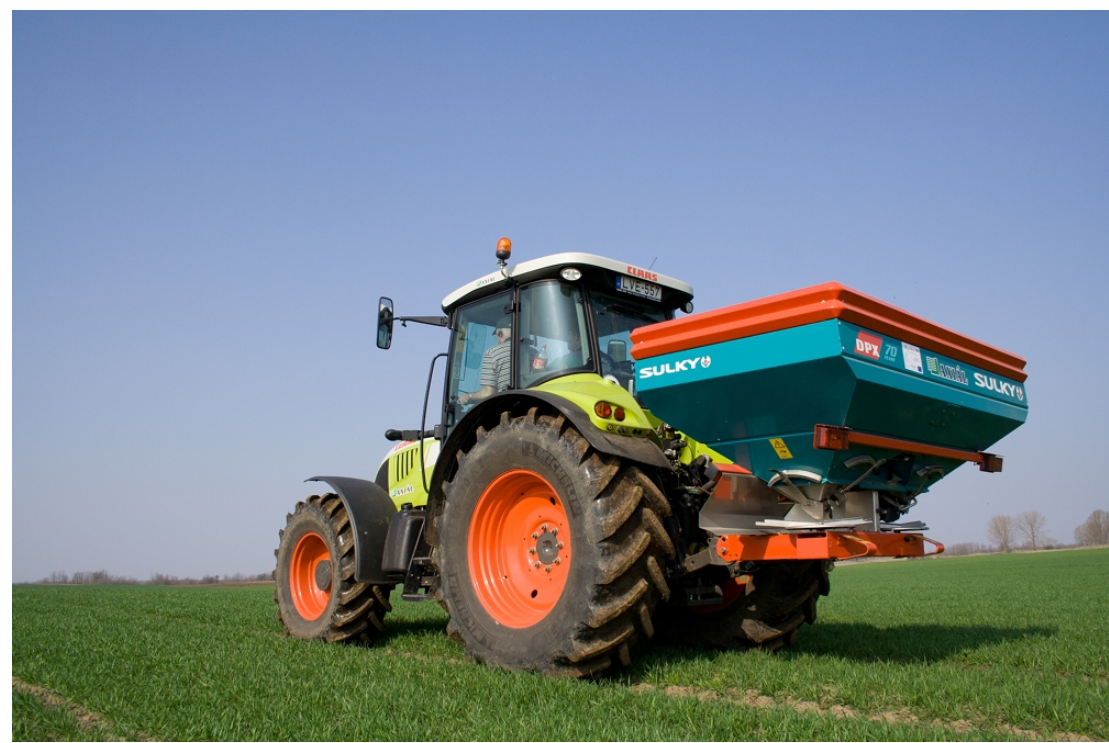

Figure 1. Fertilizer spreader [8]

Over the last decades in vain was our country's use of fertilizer was under the European average as Kádár (2005) and Németh (2007) confirmed the findings, though significant environmental impact in the agricultural output. The industrial farming is not only degraded but also in our water caused significant pollution. By the bad practice, number of agricultural fields became as nitrate sensitive areas, since the high nitrate content of the water. The water content of the two factors in relation to nitrate test. On the one hand because of the higher nutrient content, on the other hand, the aging of lakes will be accelerated greatly worsens the quality of drinkable water, all this generates a number of environmental and social problems. In addition, it should be noted the fact that the problem of water pollution not only our country, but should be considered as a global societal. The active ingredient of fertilizers in the soil left by the rains deeper soil layers, surface waters of the river waters, which are added to elute. By the rivers to the sea through the active substance, which is the time constant of the water as the world circulation. Millions accumulate chemicals, so that the local acts become global pollution damage to us one day.

\section{PROBLEM EXPLORATION}

The issue of pollution of agricultural origin nitrate is not new, but the changed climate and social circumstances increasing the timeliness of the issue. Previously, the industrial agriculture in times of high yields was only reaching with high fertilization. The quantity of the active substance in excess of the needs of the plants in the soil, remained on the surface or with rain washed down into the underground waters. Nutritional content in our lakes become bigger, so it makes eutrophication in lakes. The risk of eutrophication, to speed up the filling of lakes. Sedimentation plants lead to death of lakes and makes thick sludge. Becoming increasingly divided waters can easily become established, inter alia reeds, further 
accelerates the process of lake death. [4] Figure 2 is an example of a eutrophic lake. The reality is that the nutrients due to vegetation proliferates, the decomposition of dead plant bodies dissolved oxygen during the process. Thus the quantity of dissolved oxygen in the water decreases, resulting in the death of plants and animals, which speeds up the sedimentation by siltation of the lake intensified.

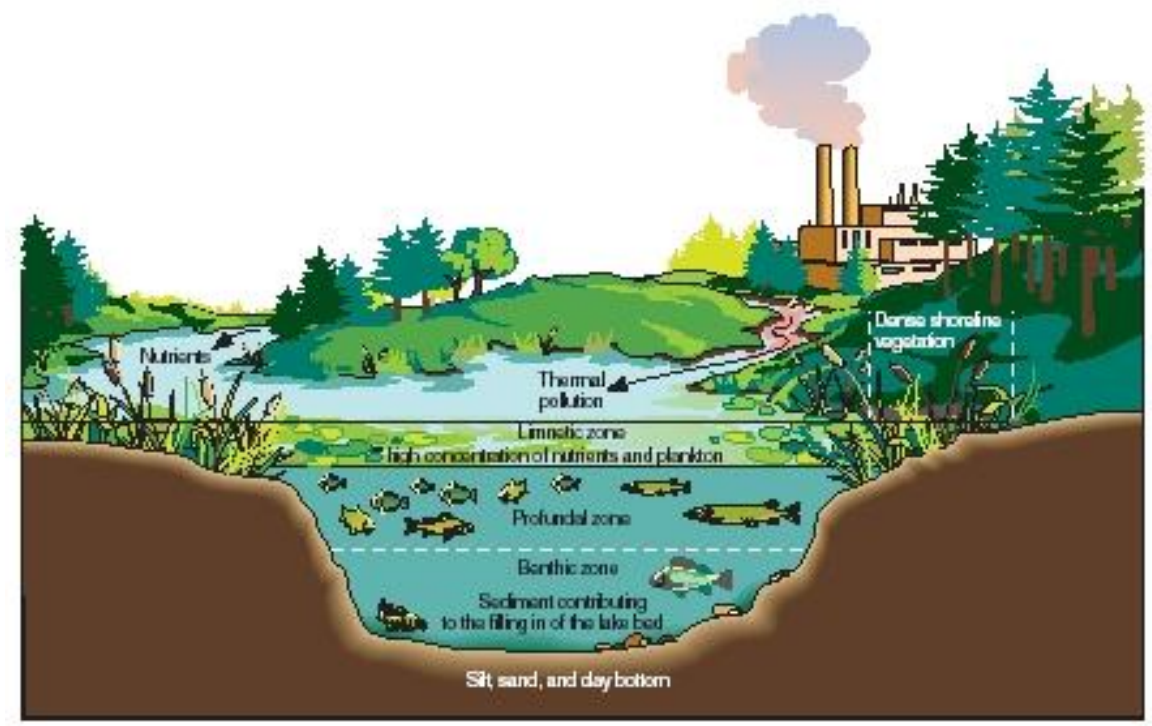

Figure 2. Eutrophic lake [9]

\section{ENVIRONMENTAL AND SOCIAL SIGNIFICANCE}

The nitrate pollution is a complex problem, environmental, social and economic problems. A point of view could not be parsed. However, you can define priorities, the imaginary is the environmental importance of the topic ranks in the first place, followed by the economic and social points of view.

The water has been transformed into not only the natural nitrification process to speed up. The faster pace of decline in the aquatic living resources. The effect of habitats or native species disrupting the balance of species disappear, the ecosystem. The disappearance of certain species to other species is affected by, for example, how to get foodstuff.

The characteristics of the areas by relaxing in the climate are subject to change, for example, could increase the temperature or humidity of the waterfront areas, reduce the extent of the water surface. Climatic change, the change in average temperature, humidity, precipitation and the amount of influence the evolution of the species comfort zone. The creatures, which are unable to adapt to the changed life parameters is expected to go away. As a result of unforeseen problems we contemplate. For example, a pest that can multiply, control, or against a minor cost not previously had to be taken, since this was the natural enemy. However, the changed conditions disappeared their natural predators so significant additional costs to protect against natural pests.

As soon as I mentioned is not only environmentally tested free of the problem. In addition to the effects on the environment are reflected in, inter alia, socio-economic problems. Contamination of the waters, and in particular the fisheries-fishing cultures (e.g. aquaculture) the possibility of maintaining population living at risk. Mind you, that the supervision of aquaculture waters supplies the fish population intense growth, however, in the case of aquaculture water nitrate-contaminated, which is environment of the production. Figure 3 presents result of pollution where the river fish are killed. 


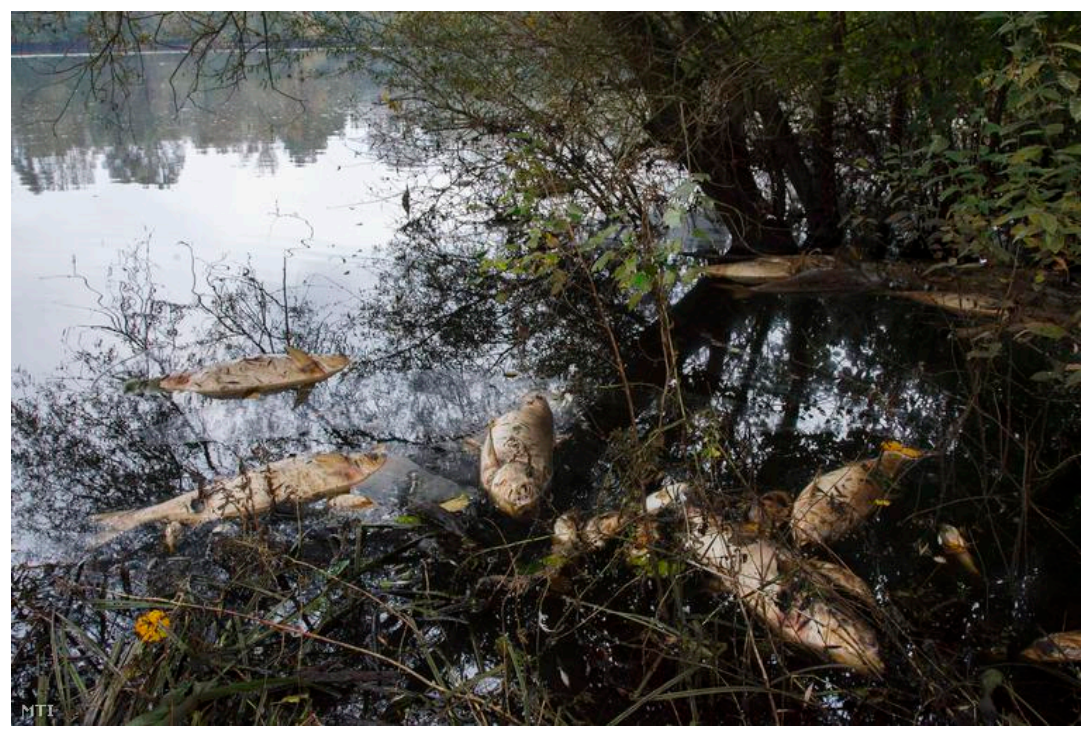

Figure 3. Fishkill in the river[10]

The same importance of water pollution seeing for the fish producers and other private people, whose primary income is the fishing. As a result of the contamination can decrease dramatically the number of the fish population, which maybe makes citizens engaging finish their fishing, which raises social issues (unemployment, supplementary aid, etc.) as well.

\section{PROPOSALS TO SOLVE THE PROBLEM}

Nitrate leaching can be reduced by proper land use and would be going through cultivation, good farming practice and good agricultural and environmental condition compliance carried out by agricultural production. In addition, positive changes could, inter alia, by the needs of the application of fertilizers plant, stages energy and nutrient needs of calculated doses. In this connection, it may be difficult for the general lack of knowledge of farmers, as more research also confirms that the aging agricultural society with a low level of education.

Typical elementary school 8 grade and secondary high school graduates are employed in agriculture. For the good agricultural practices would be required on a regular basis to learn how to participate in mandatory training sessions for workers in fishing. It means for those who do not take part any programs in which conditional on participation in training is mandatory (e.g., AKG, Natura 2000) do not get update information. They are not acquainted with the current environmental problems (e.g. nitrate contamination), and opportunities for alternative management modes in background. In addition, a new hybrid species is presented (e.g. in study farms), which is better suited to the soil and climate conditions, are also less energy input is similar to the earlier varieties yields (input-output value ratio). [5]

The level of contamination of the nitrates of agricultural origin may be reduced by applying fertilizers and slow absorption, since the soil for a longer period of time are broken down, elute, as easily absorbable form sold as fertilizers.

\section{CONCLUSIONS}

To solve the problem, it needs for public engagement. Not only must regulate the legal background in creating, checks and imposing sanctions, but the state must participate in the solution through the institutional system. The marketing and communications help, the hosts need to strengthen the 
environmental approach to the management idea of conscious as we can do at an individual level, to make a general level of society in order to solve the nitrate problem. If you recognize the farmers against bad practice to reduce nitrate pollution, it would be the solution.

It is underlined in our paper; we are faced with a complex problem. The environmental damage causes economic, social and human problems. Affected areas should not be treated separately. Source should be remedied, which in this case reducing pollution of agricultural emissions.

Instead of sanctions, needs the state economic stimulus measures designed to effectively start the process that the farmers or the social environment of a higher value, because there is just one Earth, we are for the Earth, not the opposite.

\section{REFERENCES}

[1] M. Birkás Márta, Talajművelés a fenntartható mezőgazdaságban, Akaprint, Budapest, 2001

[2] M. Birkás, Környezetkímélő alkalmazkodó talajművelés, Szent István Egyetem, Gödöllő, 2006

[3] Ismeretlen szerző (é.n.): Felszíni és felszín alatti vizek, Magyar Tudományos Akadémia, Földrajztudományi Kutató Intézet, http://www.mtafki.hu/konyvtar/Magyarorszag/Magyarorszag_terkepekben_Felszini_felszin_alatti_viz ek.pdf 2014.11.20.

[4] M. Karczag Marietta, Vizek nitrátosodásának kérdése, különös tekintettel Heves megyében, Veszprémi Egyetem Biológiai Intézet, pp. 6-7 http://binet-biotar.vein.hu/students/teljes/javitott.htm

[5] KSH, A mezőgazdaság fejlettségének regionális különbségei, http://www.ksh.hu/docs/hun/xftp/idoszaki/regiok/orsz/mgfejlettsege.pdf

[6] T. Németh, Talajaink szervesanyag-tartalma és nitrogénforgalma, MTA Talajtani és Kutató Intézet, Budapest, 2007

[7] I. Kádár, Korszakváltás a hazai mezőgazdaságban: a modern növénytermesztés alapjai, Tudományos ülés, Debrecen, 2005

[8] http://www.axial.hu/hirek/gepek/claas-arion-640-bseges-er-sallang-nelkuel/hu

[9] http://www.scienceclarified.com/El-Ex/Eutrophication.html

[10] http://index.hu/belfold/2014/10/05/tomeges_halpusztulas_somogyudvarhelyen/ 